\title{
Morphological and Chemical Analysis of Bone Substitutes by Scanning Electron Microscopy and Microanalysis by Spectroscopy of Dispersion Energy
}

\author{
Gabriela Alessandra da CRUZ \\ Sérgio de TOLEDO \\ Enilson Antonio SALLUM \\ Antonio Fernando Martorelli de LIMA \\ Department of Prosthodontics and Periodontics, \\ School of Dentistry of Piracicaba, State University of Campinas, Piracicaba, SP, Brazil
}

\begin{abstract}
This study evaluated the morphological and chemical composition of the following bone substitutes: cancellous and cortical organic bovine bone with macro and microparticle size ranging from 1.0 to $2.0 \mathrm{~mm}$ and 0.25 to $1.0 \mathrm{~mm}$, respectively; inorganic bovine bone with particle size ranging from 0.25 to $1.0 \mathrm{~mm}$; hydroxyapatite with particle size ranging from 0.75 to $1.0 \mathrm{~mm}$; and demineralized freeze-dried bone allograft with particle size ranging from 0.25 to $0.5 \mathrm{~mm}$. The samples were sputter-coated with gold in an ion coater, the morphology was observed and particle size was measured under vacuum by scanning electron microscopy (SEM). The chemical composition was evaluated by spectroscopy of dispersion energy (EDS) microanalysis using samples without coating. SEM analysis provided visual evidence that all examined materials have irregular shape and particle sizes larger than those informed by the manufacturer. EDS microanalysis detected the presence of sodium, calcium and phosphorus that are usual elements of the bone tissue. However, mineral elements were detected in all analyzed particles of organic bovine bone except for macro cancellous organic bovine bone. These results suggest that the examined organic bovine bone cannot be considered as a pure organic material.
\end{abstract}

Key Words: scanning electron microscopy, x-ray microanalysis, bone substitute, bovine bone, human bone, hydroxyapatite.

\section{INTRODUCTION}

Bone substitutes have been used to fill periodontal osseous defects around teeth affected by periodontal disease (1). Four categories of grafts are commonly used in the these days: autografts (bone from the same patient that is transferred from an intra or extra-oral donor site); allografts (bone obtained from a different donor of the same specie); xenograft (bone obtained from a different donor of another specie); and aloplastic materials or inert implants $(2,3)$.

Bone is a metabolically active organ composed of both mineral and organic phases. The mineral phase of the skeleton contributes about two thirds of its weight; the remaining one third is organic matrix, primarily consisting of collagen and small amounts of proteoglycan, lipid and several noncollagenous proteins (4).

Bone substitutes are commercially available in Brazil with different forms: organic and inorganic, cortical or cancellous, or macro and microparticle sizes, block, floccus and fragments. Bone preparation should follow rigorous quality guidelines to prevent risks of disease transmission and host rejection $(5,6)$.

Bone grafting materials may produce bone formation by osteogenesis, osteoinduction and osteoconduction. Osteogenesis is obtained by providing osteogenic cells and matrix directly to the graft by autogenous bone or bone marrow. Osteoinduction implies that the grafted material is chemotactic to undifferentiated osteoprogenitor cells in the host, attracting them to the site of the graft and inducing their differentiation into osteoblasts. Osteoconduction is a process that allows outgrowth of osteogenic cells from exposed bone surfaces into adjacent graft material, such as calcium phosphate that acts as an inert scaffold $(5,7,8)$.

Histological and scanning electron microscopic studies have shown morphological analyses of bone substitute particles, including particle size measurements (3,5,9-12), and suggested that particle size may interfere with the osteoclastic cell resorption activity (12). 
Scanning electron microscopy (SEM) provides rich visual details and accuracy for measurements of particle size. Microanalyses by spectroscopy of dispersion energy (EDS) allows quantitative and qualitative evaluations of the mineral components when the device is coupled with a correcting system (Proza) that assesses the atomic number (Z), absorption (A) and fluorescence (F) of the elements in the samples. EDS microanalyses allow verifying a small particle region without physically separating this part from the material (13).

In view of the lack of published information regarding the actual particle size and chemical composition of commercially available bone substitutes, the purpose of this study was to analyze, by SEM and EDS microanalysis, the shape, size and chemical composition of the particles of the following bone substitutes: cancellous and cortical organic bovine bone with macro and microparticle size; inorganic bovine bone; hydroxyapatite; and freeze-dried bone allograft.

\section{MATERIAL AND METHODS}

Particle batches of the following materials were obtained: 1 . organic cortical bovine bone with macro and microparticle sizes ranging from 1.0 to $2.0 \mathrm{~mm}$ and 0.25 to $1.0 \mathrm{~mm}$, respectively (Gen-ox ${ }^{\circledR}$; Baumer S/A, Division of Biomaterials, Mogi Mirim, SP, Brazil); 2. organic cancellous bovine bone with macro and microparticle sizes ranging from 1.0 to $2.0 \mathrm{~mm}$ and 0.25 to $1.0 \mathrm{~mm}$, respectively $\left(\right.$ Gen-ox $\left.{ }^{\circledR}\right)$; 3. inorganic bovine bone with particle size ranging from 0.25 to $1.0 \mathrm{~mm}$ (Bio-Oss, Geistlich-Pharma, Wolhusen, Switzerland); 4. demineralized freeze-dried bone allograft with particle size ranging from 0.25 to $0.50 \mathrm{~mm}$. (Dembone, Pacific Coast Tissue Bank, Los Angeles, CA, USA). 5. natural mineral hydroxyapatite bovine bone with rough granulation particle size ranging from 0.75 to $1.0 \mathrm{~mm}$ (Pro-Ha, Pró-line, São Paulo, SP, Brazil). Samples were purchased from materials' commercial representatives.

\section{SEM Analysis}

The materials' particles were fixed on stubs with carbon tape or adhesive containing powdered graphite (Ceil, São Paulo, SP, Brazil) and sputter-coated with gold in an ion coater (Denton Desk II, Denton Vacuum LLC, Moorestown, NJ, USA). Particle size and morphology were examined under vacuum with a scanning electron microscope (JSM 5600LV, Jeol, Tokyo, Japan). Visual morphological analysis was done using a specific software (SEM Control User Interface, version 1.27, Jeol). Particle size measurements were undertaken in 20 particles of each bone substitute, according to the highest longitudinal dimension and were expressed using descriptive statistics.

\section{EDS Microanalysis}

The chemical composition of the particles was evaluated by EDS microanalysis (Noran Vantage EDS, version 1.4, Noran Instruments, Inc., Tokyo, Japan) under vacuum on uncoated samples fixed on stubs with carbon tape or adhesive containing powdered graphite (Ceil). The analysis was performed after selecting an area on standard SEM photomicrographs acquired with $15 \mathrm{kVp}, 20 \mathrm{~mm}$ of distance and spot sized 33. The quantitative analysis of bone substitutes was performed with a correcting system (PROZA) (Noran Vantage EDS, version 1.4, Noran Instruments, Inc.) that assesses the atomic number $(\mathrm{Z})$, absorption (A) and fluorescence $(\mathrm{F})$ of the elements present in the samples areas.

\section{Statistical Analysis}

Particle size data were expressed by descriptive statistics using specific softwares (Statistix for Windows, v. 7.0, 2000, StatSoft South America, São Caetano do Sul, SP, Brazil and Minitab for Windows, v. 13.1, 2001, Minitab, Inc., State College, PA, USA). EDS microanalysis data were expressed as the percentage of elements in the samples and by the spectrographics showing counter time and electron volt energy.

\section{RESULTS AND DISCUSSION}

This study was designed to evaluate the shape, size and chemical composition of organic and inorganic bovine bone, demineralized freeze-dried bone and hydroxyapatite. These materials are commercially available for periodontal regenerative procedures $(4,6,12,14)$.

The morphological analysis of the particles of the substitute from organic and inorganic bovine bone, demineralized freeze-dried bone and hydroxyapatite showed particle of irregular shape (Fig. 1). The demineralized freeze-dried bone and cancellous organic bovine bone exhibited larger porous than the cortical 
organic bovine bone. The hydroxyapatite showed no porosity (Fig. 2), which is in accordance with previous studies $(15,16)$. However, it has been suggested that it is possible to modify the hydroxyapatite structure to obtain porosity, allowing bone cell infiltration as it seems that pore colonization is favored by diameters larger than 50-100 mm or even $250-300 \mathrm{~mm}$ (17). However, a previous study (7) did not report bone growth in pores smaller than $50 \mathrm{~mm}$. Figure 2 shows the presence of pores with different sizes in the tested materials.

Particle size analysis showed some discrepancy between the obtained values and the values informed on the product label. The microparticles of cancellous organic bovine bone showed a mean size of $1.19 \pm 0.29$ $\mathrm{mm}$ (label information: microparticles ranging from 0.25 to $1.0 \mathrm{~mm}$ and macroparticles ranging from 1.0 to $2.0 \mathrm{~mm}$ ), whereas the smallest particle size was presented by the demineralized freeze-dried bone (0.97 \pm $0.31 \mathrm{~mm}$ ) (label information: 0.25 to $0.50 \mathrm{~mm}$ range). Such a discrepancy has been previously reported by

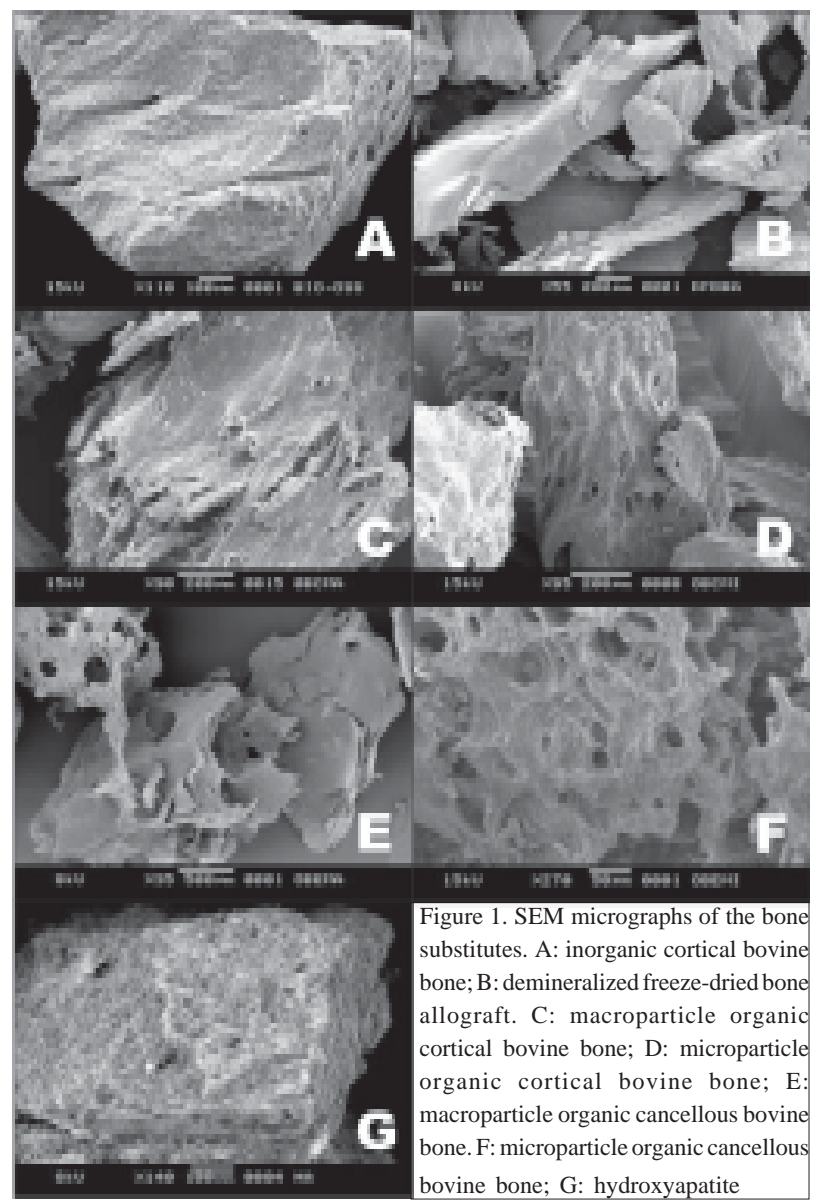

Schwartz et al. (4) while evaluating the size of demineralized freeze-dried bone particles. The largest particle sizes were presented by the macroparticle cancellous organic bovine bone $(2.54 \pm 0.31 \mathrm{~mm})$ and macroparticle cortical organic bovine bone $(2.01 \pm 0.35 \mathrm{~mm})$. The microparticle size of cortical organic bovine bone (1.33 \pm 0.28 ), microparticle size of inorganic bovine bone $(1.31 \pm 0.41 \mathrm{~mm})$ and hydroxyapatite $(1.43 \pm 0.41 \mathrm{~mm})$ showed intermediate length values (label information: particles ranging from 0.75 to $1.0 \mathrm{~mm}$ ). These data suggest that all evaluated materials showed larger particle sizes than those informed by the manufacturers.

It is well accepted that the particle size may interfere with the success of the regenerative therapy. When demineralized freeze-dried bone is used, particle sizes ranging from $0.12 \mathrm{~mm}$ to $1.00 \mathrm{~mm}$ possess a higher osteoinductive effect than do particles below $0.12 \mathrm{~mm}$ (5). Apparently, the ideal particle size should range from $0.10 \mathrm{~mm}$ to $0.30 \mathrm{~mm}$. Very small particle sizes of demineralized freeze-dried bone may elicit a

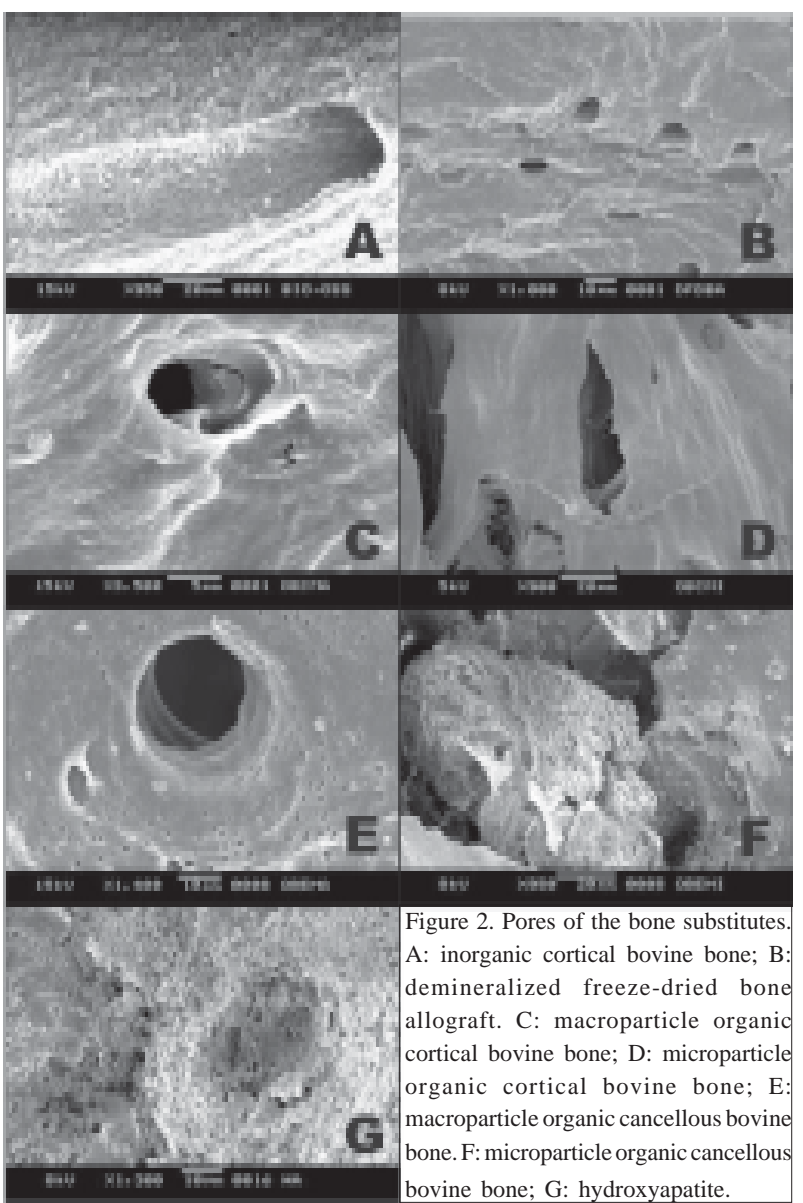


macrophage response and are rapidly resorbed with little or no new bone formation (5). However, Fucini et al. (14) found no differences after clinical application of two different sizes of demineralized freeze-dried bone (0.25 and $0.50 \mathrm{~mm}$; and 0.85 and $1.00 \mathrm{~mm}$ ).

EDS microanalysis of bovine bone matrix, human bone and hydroxyapatite detected elements, like calcium, phosphorus, aluminum and sulfur (Fig. 3). These are expected findings (18) as these chemical elements could be incorporated during bone development and $\mathrm{Ca} / \mathrm{P}$ ratio may vary according to nutritional conditions. Normal bone composition should include
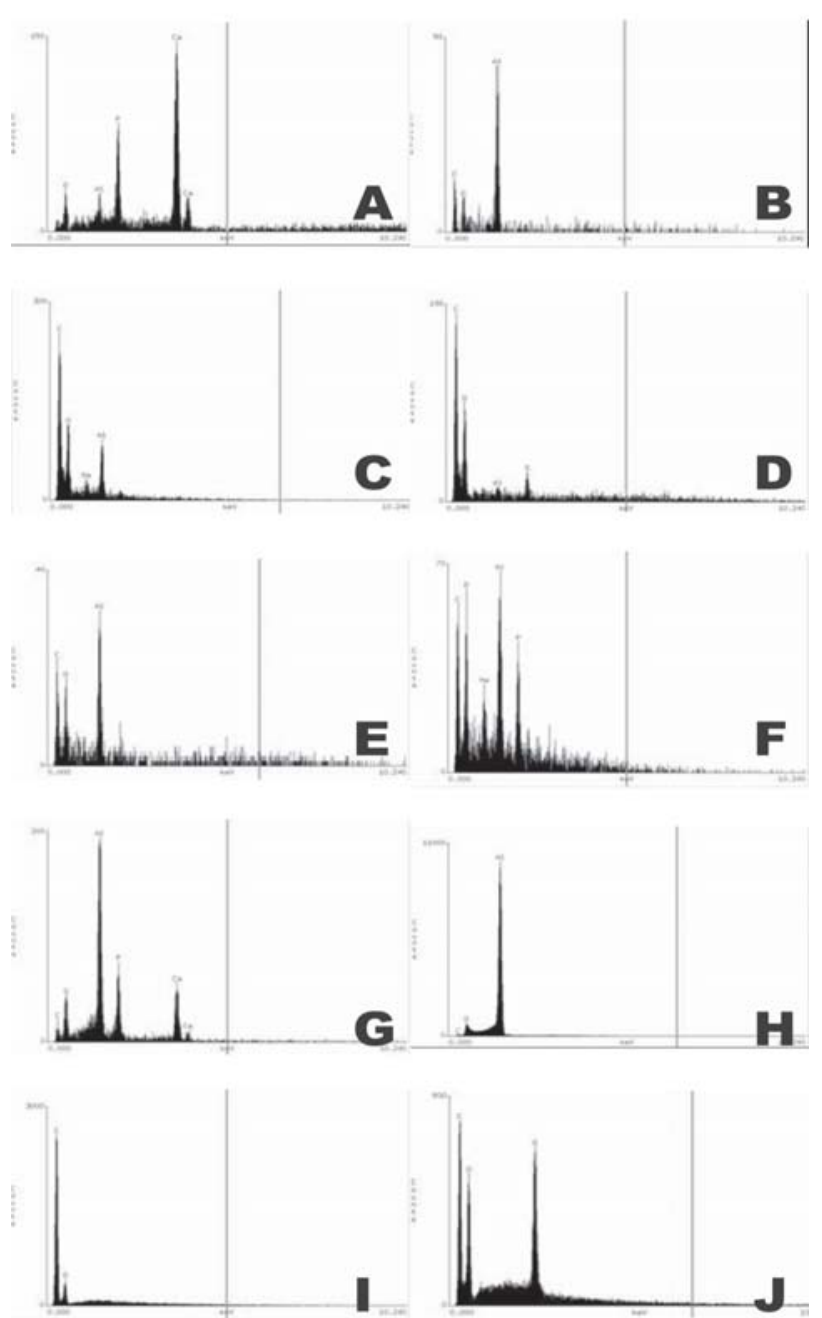

Figure 3. Spectrographic showing the chemical elements detected in the samples by EDS microanalysis. A: inorganic cortical bovine bone; B: demineralized freeze-dried bone allograft; C: macroparticle organic cortical bovine bone; D: microparticle organic cortical bovine bone; E: macroparticle organic cancellous bovine bone; F: microparticle organic cancellous bovine bone; G: hydroxyapatite; H: stub; I: carbon tape; J: adhesive. magnesium, sodium, potassium and carbonate salts (18). Table 1 displays the quantitative analysis with PROZA correcting system. Mineral elements were detected in micro and macro cortical organic bovine bone and micro cancellous organic bovine bone.

Thus, it may be assumed that the evaluated organic bovine bone could not be considered as a pure organic material (i.e., collagen and proteins) except for the macro cancellous bovine bone that did not show any mineral elements. The analysis of inorganic bovine bone and hydroxyapatite detected calcium and phosphor that are usual chemical elements of their compositions.

Merkx et al. (19) found similar morphostructural and chemical elements in the inorganic bovine bone and concluded that bovine bone composition seems to be the same as that of human bone. The presence of aluminium could be attributed to the type of stub used. Carbon and oxygen could not be quantified because their anatomic numbers are lower than that of sodium and the equipment was not calibrated for this type of analyses (19).

SEM analysis showed that the particles of the bone substitutes have irregular shape and size. Particle sizes tended to be lager than those mentioned on product label. EDS microanalyses detected the presence of chemical elements that are typical of bone tissue. Further research is required to thoroughly describe the

Table 1. Percentage of the chemical elements detected in the particles of inorganic cortical bovine bone (BIO-OSS), demineralized freeze-dried bone allograft (DFDBA), macroparticle organic cortical bovine bone (MaOCoBB), microparticle organic cortical bovine bone (MiOCoBB), macroparticle organic cancellous bovine bone (MaOCaBB), microparticle organic cancellous bovine bone (MiOCaBB), hydroxyapatite particles (HA), stub, carbon tape and adhesive.

\begin{tabular}{lcccccc}
\hline & & \multicolumn{5}{c}{ Chemical elements (\%) } \\
\cline { 3 - 7 } Materials & Time (s) & $\mathrm{Na}$ & $\mathrm{P}$ & $\mathrm{Ca}$ & $\mathrm{S}$ & $\mathrm{Al}$ \\
\hline & & & & & & \\
BIO-OSS & 150 & - & 17.59 & 79.45 & - & 2.96 \\
DFDBA & 50 & - & - & - & - & 100.0 \\
MaOCoBB & 300 & 21.19 & - & & & 78.81 \\
MiOCoBB & 190 & - & - & - & 81.79 & 18.21 \\
MaOCaBB & 40 & - & - & - & - & 100.0 \\
MiOCaBB & 70 & 16.50 & 37.88 & - & - & 45.62 \\
HA & 200 & - & 22.08 & 26.39 & - & 44.40 \\
Stub & 11000 & - & - & - & - & 100.0 \\
Carbon tape & 3000 & - & - & - & - & 100.0 \\
Adhesive & 800 & - & - & - & 100.0 & - \\
\hline
\end{tabular}


characteristics of these materials and to determine their role in the treatment of periodontal osseous defects.

Under the tested conditions, it may be concluded that: 1 . The evaluated materials presented particles of irregular shape and size. 2 . The mean measured particle sizes were larger than the sizes informed by the manufacturers. 3. The analysis of chemical composition by EDS detected the presence of sodium, calcium and phosphorus that are common chemical elements on bone tissue composition; 4. Mineral elements were detected on all particles of organic bovine bone, except for macro cancellous organic bovine bone, which suggest that the evaluated organic bovine bone could not be considered as a pure organic material.

\section{RESUMO}

Neste estudo foram avaliados a morfologia, o tamanho e a composição química dos seguintes substitutos ósseos: osso bovino orgânico cortical e esponjoso com micropartículas medindo entre 0,25 e 1,0 mm e macropartículas medindo entre 1,0 e 2,0 mm; osso bovino cortical inorgânico com partículas medindo entre 0,25 e 1,0 mm; hidroxiapatita com partículas medindo entre 0,75 e 1,0 mm; e osso humano descalcificado, congelado e seco medindo entre 0,25 a $0,5 \mathrm{~mm}$. Para a analise da morfologia e tamanho das partículas, as amostras foram preparadas em porta-espécime, metalizadas em ouro e analisadas a vácuo em microscopia eletrônico de varredura (MEV). Para a análise da composição química, as partículas não foram metalizadas e foram analisadas por microanálise por espectroscopia por dispersão de energia (EDS). A análise em $\mathrm{MEV}$, demonstrou que as partículas substitutos ossos apresentaram formato irregular e tamanho variável, maior do que o mencionado pelo fabricante. A microanálise por EDS detectou a presença de elementos como sódio, cálcio e fósforo, que são comuns à composição do tecido ósseo, porém revelaram a presença de elementos químicos nas partículas de osso bovino orgânico, exceto para a macropartícula de osso bovino orgânico esponjoso. Esses resultados sugerem que o osso bovino orgânico não pode ser considerado um material orgânico puro.

\section{ACKNOWLEDGEMENTS}

To Professor Ivan Balducci, University School of Dentistry of São José dos Campos/UNESP, for assistance with statistical analysis.

\section{REFERENCES}

1. Persson GR, Falk H, Laurell L. A retrospective radiographic outcome assessment study of intra-bony defects treated by osseous surgery or by bone graft procedures. J Periodontol 2000;27:104-108.

2. Betz, R.R. Limitations of autograft and allograft: new synthetic solutions. Orthopedics 2002;25:561-570.

3. Cordioli G, Mazzocco C, Schepers E, Brugnolo E, Majzoub Z.
Maxillary sinus floor augmentation using bioactive glass granules and autogenous bone with simultaneous implant placement. Clinical and histological findings. Clin Oral Impl Res 2001;12:270-278.

4. Schwartz Z, Goultschin J, Dean DD, Boyan BD. Mechanisms of alveolar bone destruction in periodontitis. Periodontology 2000 1997;14:158-172.

5. American Academy Periodontology. Position paper. Tissue banking of bone allografts used in periodontal regeneration. J Periodontol 2001;72:834-838.

6. Melloning JT. Freeze-dried bone allografts in periodontal reconstructive surgery. Den Clin North Amer 1991;35:505522.

7. Ikeda N, Kawanabe K, Nakamura T. Quantitative comparison of osteoconduction of porous, dense A-W glass ceramic and hydroxyapatite granules (effects of granules and pore size). Biomaterials 1999;20:1087-1089.

8. Suh H, Han D, Park J, Lee DH, Lee WS, Han CD. A bone replaceable artificial bone substitute: osteoinduction by combining with bone inducing agent. Artificial Organs 2001;25:459-466.

9. Artzi Z, Tal H, Dayan D. Porous bovine bone mineral in healing of human extraction sockets: 2. Histochemical observations at 9 months. J Periodontol 2001;72:152-159.

10. Artzi Z, Nemcovsky CE, Dayan D. Bovine-HA spongiosa blocks and immediate implant placement in sinus augmentation procedures. Histopathological and histomorphometric observations on different histological staining in 10 consecutive patients. Clin Oral Impl Res 2002;13:420-427.

11. Stephan EB, Jiang D, Lynch S, Bush P, Dziak R. Anorganic bovine bone supports osteoblastic cell attachment and proliferation. J Periodontol 1999;70:364-369.

12. Tadjoedin ES, De Lange GL, Bronkers ALJJ, Layaruu DM, Burger EH. Deproteinized cancelous bovine bone (Bio-OSS ${ }^{\circledR}$ ) as bone substitute for sinus floor elevation. A retrospective, histomorphometrical study of five cases. J Clin Periodontol 2003;30:261-270.

13. Goldstein JI, Newburry DE, Joy DC, Lyman CE, Echlin P, Lifshin E et al. Scanning electron microscopy and x-ray microanalysis. 3rd ed. New York: Plenum Press; 2003.

14. Fuccini ES, Quintero G, Gher ME, Black BS, Richardson AC. Small versus large particles of demineralized freeze-dried bone allografts in human intrabony periodontal defects. J Periodontol 1993;64:844-847.

15. Frank RM, Klewansky P, Hemmerle J, Tenenbaum H. Ultra structural demonstration of the importance of crystal size of bioceramic powers implanted into human periodontal lesions. J Clin Periodontol 1991;18:669-680.

16. Valdre G, Mongiorgi R, Ferrieri P, Corvo G, Cattaneo V, Tartaro GP. Scanning electron microscopy (SEM) and microanalysis (EDS) applied to the study of biomaterial for dental use. Minerva Stomatol 1995;44:55-68.

17. Engin NO, Tas AC. Manufacture of macroporous calcium hydroxyapatite bioceramics. J Eur Ceram Soc 1999;19:25692572 .

18. Guyton AC. Textbook of Medical Physiology. 8th ed. Philadelphia: WB Saunders, 1993.

19. Merkx AWM, Maltha JC, Freihofer MH, Kuijpers-Jagtman AM. Incorporation of particulated bone implants in the facial skeleton. Biomaterials 1999;20:2029-2035.

Accepted October 30, 2006 